•中国国家公园建设专题・

\title{
完善法律法规，依法保障国家公园体制稳步建设
}

\author{
王风春*
}

(全国人大环境与资源保护委员会法案室, 北京 100805)

\section{Steadily promoting the progress of the national park system reform through the perfectness of national park legislation}

Fengchun Wang*

Environment Protection and Resources Conservation Committee, National People's Congress (NPC), P. R. C. Beijing 100805

随着国家公园体制试点和体制改革的推进，如 何建立形成国家公园法律法规及配套规范标准体 系，为国家公园设立和管理提供有效的法治保障， 已经成为当前一项重大而又紧迫的任务。从建立国 家公园体制所面临的现实问题和《建立国家公园体 制总体方案》(以下简称《总体方案》) 的各项要求 与任务来看, 在建立形成有关国家公园的法律法规 过程中，应当首先注意以下基本情况和问题:

一是如何在现行自然保护地管理体系和法律 法规基础上重新构建有关国家公园的法律法规。中 国的国家公园体制和有关法律法规不是在一张白 纸上描绘出来的。经过 60 多年的发展, 中国已经基 本形成了以自然保护区、风景名胜区、地质公园和 森林公园等为主体, 以多部门分管地方管理为主的 自然保护地体系。现行有关环境与资源的法律中分 别设定了近10种自然保护地类型，包括自然保护 区、风景名胜区、饮用水水源保护区、海洋特别保 护区、种质资源保护区、禁猎区、天然林保护区等; 有关行政法规和规章中设定了森林公园、地质公 园、湿地公园、水利风景区等; 依照相关国际公约, 在国内各种保护区的基础上设立了世界遗产、世界 地质公园、国际重要湿地等。以《自然保护区条例》、 《风景名胜区条例》等为核心, 确立了有关自然保 护地设立、规划、管理等的一系列基本制度和相应 的标准与技术规范。如何在现行的管理体系和法律 法规“图画”上描绘出有关国家公园法律法规的新蓝
图，是我们首先面临的问题。

二是如何做到制度建设和改革同步，使建设国 家公园体制于法有据, 依法保障。这是与上一问题 密切相关的问题。党的十八大以来, 中共中央把全 面深化改革和全面推进依法治国作为新时期推进 国家治理体系现代化的重大战略举措, 提出了改革 要于法有据和依法保障的基本要求, 建设新型的国 家公园体制也不例外。纵观世界各国特别是美国、 加拿大、澳大利亚、新西兰、南非等国国家公园及 其他各种自然保护地的形成和发展历程, 可以看到 其有关法律法规通常是同步建立形成的(其中有些 国家每个国家公园还要通过议会专项法案批准设 立), 严格依法设立和管理国家公园, 包括依法划定 边界和明确土地及有关资源权属, 依法设立管理机 构和安排预算资金，严格规范资源利用和相关人为 活动, 为国家公园等自然保护地的生态系统(包括 其中的历史人文遗迹)的完整保护和可持续利用, 奠定了坚实可靠的法律基础和制度保障。国家严格 依法设立和管理国家公园的有关经验和作法, 值得 认真加以研究和借鉴。

三是如何通过有关国家公园立法, 有效解决当 前国家公园以及自然保护地所面临的突出问题。应 当强调的是, 国家公园基本上是在现行自然保护 区、风景名胜区等自然保护地基础上优选、整合而 成，构建国家公园体制同完善自然保护地体系密不 可分, 要建立国家公园体制, 首先要为有效解决当

收稿日期: 2017-10-18; 接受日期: 2017-10-20

* 通讯作者 Author for correspondence. E-mail: wfengchun@npc.gov.cn 
前自然保护地分类混杂、定位不清、管理重叠、保 护不力的问题。为此, 在《总体方案》的有关目标 和重点任务中, 提出了 “构建统一规范高效的中国 特色国家公园体制”和“分类科学、保护有力的自然 保护地体系”两个密切相关的任务。相应的, 研究制 定有关国家公园的法律法规就不是单纯制定“国家 公园法”或者 “国家公园条例”的问题，而是要同时 建立健全国家公园以及自然保护地法律法规体系 框架、行政管理体制和各项基本法律制度的问题。

因此, 按照生态文明制度建设的基本要求和 《总体方案》的重点任务, 迫切需要在自然保护地 科学合理分类的基础上, 根据国家公园体制建设中 遇到的问题和实际情况, 研究修改现行的相关法律 法规以及标准与技术规范, 逐步建立形成适应国家 公园以及自然保护地体系创新发展的法律法规和 标准与技术规范体系。当前需要循序做好以下工作:

一是抓紧评估现行自然保护区、风景名胜区、 文化自然遗产、地质公园、森林公园等的法律规定 和行政规范, 在法律上确立包括国家公园在内的完 整自然保护地分类体系。根据新的分类体系和《总 体方案》的主要内容, 修改现行各项环境与资源法 律法规及民事、刑事法律中不相适应的规定, 增补 有关国家公园的规定, 特别要衔接好各项法律中有 关国家公园和其他自然保护地的法律规范, 避免出 现交叉重叠及冲突性的法律规定。从长远考虑, 也 应着手研究国家公园入宪的问题, 在宪法中确立国 家公园的法律地位和保护的基本原则。

二是加紧研究建立以国家公园法律法规为核 心的自然保护地法律法规框架体系。目前社会各界 已就国家公园立法提出了多种意见和方案, 主要有 制定综合的自然保护地法(包括有关国家公园的具 体规定)和制定单项的国家公园法及单项的自然保 护区法、风景名胜区法等两种思路。前者的优点是 可从法律上统一分类和规范国家公园和自然保护 区、风景名胜区等自然保护地, 后者的优点是突出 国家公园的国家代表性及其重要法律地位。只要各 种自然保护地分类科学、关系清晰, 两种思路在内 容上可能并没有实质性差别。但从国家公园在自然 保护地体系的核心地位和国家代表性来讲, 单独制 定国家公园法对宣示国家保护国家公园的意志、彰 显国家公园的法律地位具有重要意义; 同时, 可兼
顾自然保护地体系的系统性, 在国家公园法中对自 然保护地分类和管理作出原则性规定, 并相应修改 现行自然保护区、风景名胜区条例等, 构建起以国家 公园法为核心的法律法规体系。这不失为一种较好 的立法思路, 值得认真研究论证。从立法路径上, 也 可考虑先制定条例，实施一定时期再上升为法律。

三是加快研究制定有关国家公园的法律法规 框架和基本法律制度体系。《总体方案》以及各个 国家公园体制试点方案, 实际上已经原则提出了国 家公园法律法规的法律框架和基本法律制度，如国 家公园的基本定义、立法目的、基本原则、管理体 制、设立程序和涉及总体规划、功能分区、调查与 监测、产权与资产、协议保护、特许经营、行政监 管、社区共管、公众参与、生态补偿、资金保障、 责任追究等方面的管理制度和措施, 为在《总体方 案》实施过程中把其总结提升为法律规范奠定了较 好的基础。下一步应注意调查、评估《总体方案》 各项管理制度的实施情况，在坚持《总体方案》的 指导思想、基本原则、主要目标和国家公园内涵的 基础上, 根据试点情况, 建立健全各项管理制度, 研究制定国家公园法, 尽早列入全国人大立法计划, 尽快形成严整可行的法律制度体系。

四是加快研究制定有关国家公园的标准与技 术规范体系。国家公园的标准与技术规范是国家公 园法律法规体系的重要组成部分, 是有关法律法规 实施的重要前提和基础条件。当前最为急迫的是加 快制定包括国家公园在内的自然保护地分类标准 与技术规范和国家公园设立的标准与技术规范, 这 是国家公园试点和《总体方案》科学稳步实施的基 本前提条件; 同时, 认真参照自然保护区、风景名 胜区有关标准与技术规范，借鉴有关国家和国际组 织的标准与技术规范, 并结合试点所取得的经验, 加快制定有关国家公园规划、功能分区、调查与监 测、设施建设与管理、园区巡护、防火防灾、科研 与旅游活动、管理指标与评估等方面的标准与技术 规范，以及涉及生物多样性体系调查、监测、科研 和物种保护与管理等方面的标准与技术规范, 尽快 形成由法律、法规和部门规章以及配套的标准与技 术规范所组成的、系统完整的国家公园法律法规体 系, 为《总体方案》的顺利实施和国家公园体制的 稳步建设奠定良好的法治条件和管理基础。 